\title{
ВПЛИВ ФАКТОРІВ СЕРЕДОВИЩА ЖИТТЕДІЯЛЬНОСТІ ЛЮДИНИ НА РИЗИК ВИНИКНЕННЯ ІНФЕКЦІЙНИХ ХВОРОБ
}

\author{
Науково-координаційне управління НАМН України, Українська військово-медична академія
}

\begin{abstract}
Висвітлено питання інфрекційної захворюваності, окреслено ії загальні тенденції та регіональні особливості, оскільки в Україні щорічно в епідемічний процес залучаються широкі верстви населення, з яких до 8-9 млн осіб звертається за медичною допомогою. 3 метою встановлення динаміки інфекційного процесу було проведено ретроспективний епідеміологічний аналіз, який базувався на вивченні багаторічної захворюваності населення країни за даними галузевої звітності МОЗ України та Держсанепіднагляду. Розрахунок коефріцієнта кореляції дозволив виявити щільність зв'язку між чинниками середовища життєдіяльності людини та ризиком виникнення інфрекційних хвороб, а метод простого ранжування - розставити регіони країни в порядку їх значущості за різними критеріями, починаючи від чисельності населення чи рівня людського розвитку, і закінчуючи показниками інсрекційної захворюваності. Проведений епідеміологічний аналіз 3 побудовою трендової моделі виявив, що в Україні спостерігається погіршення стану здоров'я населення, про що свідчить збільшення на 55 \% показника поширеності хвороб за всіма класами та Індекс накопичення хвороб $(1,4)$. Інфекційна та паразитарна захворюваність набула тенденції до зниження, ії питома вага в загальній структурі хвороб не перевищує $4 \%$, однак зросла кількість залучених в епідемічний процес осіб похилого віку. Захворюваність має регіональні відмінності, зокрема висока поширеність цієї патології притаманна АР Крим, Волинській, Дніпропетровській, Донецькій, а найнижча - Закарпатській та Тернопільській областям.
\end{abstract}

На інфрекційну захворюваність, з поміж іншого, впливає щільність проживання населення $\left(r_{s}=0,4\right.$; $p<0,05)$, а також рівень людського розвитку регіонів, зокрема економічні показники $(r=0,9 ; p<0,01)$, від яких залежить доступність медичної допомоги. Ризик виникнення інфрекційних хвороб зростає внаслідок погіршення умов середовища життєдіяльності людини, зокрема через відсутність у населення регіонів можливості використовувати не лише свіжу ( $r=0,9 ; p>0,01)$, а насамперед безпечну воду; високий рівень вироблених відходів $(r=0,4 ; p<0,05)$; збільшення обсягів викидів забруднюючих речовин в атмосфрерне повітря ( $r=0,9$; $p<0,01)$ та через інші фрактори, які прямо чи опосередковано можуть впливати на здоров'я населення.

Ключові слова: захворюваність, поширеність, ретроспективний епідеміологічний аналіз, кореляційний аналіз.

Актуальність інфекційних хвороб обумовлена залученням в епідемічний процес широких верств населення; високим, незважаючи на застосовувані профрілактичні заходи, рівнем смертності. В Україні щорічно за медичною допомогою звертаються мільйони українців, з них до 8-9 млн з приводу інфекційних та паразитарних захворювань, насамперед, гострих респіраторних інфекцій та грипу, кишкових інфекцій, туберкульозу, ВІЛ/СНІДу, паразитозів. Значна кількість хворих залишається поза медичною статистикою через самолікування. Показники інсрекційної та паразитарної захворюваності останніми роками знизились, проте по багатьох нозологіях продовжують перевищувати аналогічні в провідних країнах Європи. Від інсрекційних хвороб гинуть тисячі українців, у тому числі й діти, при тому, що їх питома частка в загальній структурі первинної захворюваності серед всього населення України не перевищує $4 \%[1-4]$.

Інфекційний процес залежить від рівня сприйнятливості організму людини чи тварин до впливу хвороботворних мікроорганізмів та їх біологічних властивостей, однак і ті й інші чутливі до дії різноманітних фракторів середовища життєдіяльності. Поширенню інсрекцій можуть сприяти чи, навпаки, уповільнювати цей процес соціально-економічні та екологічні чинники, такі як зростання чисельності населення, його щільність і рух, урбанізація, зміни в землекористуванні, зміни клімату та поведінки людини, впливаючи на ефрективність профрілактичних заходів [5-9].

\section{Матеріали і методи}

3 метою встановлення динаміки інфекційного процесу було проведено ретроспективний епідеміологічний аналіз, 
який базувався на вивченні багаторічної захворюваності населення України за даними галузевої звітності МОЗ України (фрорми № 33-здоров, 12 та 47, затверджені наказами МОЗ України від 10.07.2007 № 378, від 27.07.2006 № 524) та Держсанепіднагляду (фр. № 1 та 2, затверджені наказом МОЗ України від 2.06.2009 № 378) [1].

Здійснений кореляційний аналіз дозволив виявити силу та характер впливу різноманітних чинників середовища життєдіяльності людини на ризик виникнення інфекційних хвороб. Для всіх пар порівнюваних величин було розраховано коефіцієнт кореляції, що дозволяє виявляти щільність зв'язку між результативними і фракторними ознаками у кореляційно-регресійній моделі за лінійної залежності. Метод простого ранжування дозволив розставити регіони країни в порядку їх значущості за різними критеріями, починаючи від чисельності населення, закінчуючи показниками інсекційної захворюваності. Ранги позначались цифррами від 1 до $n$, де $n$ - кількість рангів. Дослідження ймовірності існування залежності між показниками поширеності інфекційних хвороб та індексом людського розвитку регіонів було здійснено за допомогою методу аналізу непараметричних рангових коесріцієнтів зв'язку, зокрема рангового коефріцієнту Спірмена.

\section{Результати досліджень та їх обговорення}

Проведений ретроспективний епідеміологічний аналіз з побудовою трендової моделі виявив, що в Україні спостерігається погіршення стану здоров'я населення, про що свідчить зростання показника поширеності хвороб за всіма класами, визначеними Міжнародною статистичною класифікацією хвороб та споріднених проблем охорони здоров'я десятого перегляду хвороб (коефіцієнт достовірності апроксимації $\left(\mathrm{R}^{2}\right)$ складає 0,94 ( $<<0,01)$. У 2013 р. (останній рік, коли враховувались статистичні дані з усіх регіонів України) стосовно 1994 р. поширеність хвороб за всіма класами зросла на 55,1%. Індекс накопичення хвороб $(1,4)$, незважаючи на незначне коливання в розрізі регіонів країни, від 1,2 у Запорізькій області до 1,5 у Київській, Волинській, Донецькій, Чернівецькій, Чернігівській областях, свідчить про переважання хронічних фрорм захворювань над гострими.

За умови, що захворювання, віднесені до Класу I «Деякі інсрекційні та паразитарні хвороби» (А00-В99) частково включені до інших класів хвороб, приміром гострі респіраторні захворювання та грип, серед патології, вперше виявленої, в 1994 р. їх питома вага складала 5,02 \%. Через переважно гострий клінічний перебіг (індекс накопичення -1,2), серед всіх хвороб, поширених серед населення, інфекційні становили 3,6 \%. У 2013 р. частка інфекційних і паразитарних хвороб у загальній структурі захворюваності та поширеності зменшилась до 3,9 та 2,2 \%, відповідно.
Показники іноекційної та паразитарної захворюваності упродовж 1994-2013 рр. складали в різні роки від 2,6 до 3,1 тисяч випадків, а поширеності - від 3,9 до 4,5 тисяч випадків на 100 тис. населення. Незважаючи не невисокі, порівняно 3 іншими класами, показники захворюваності та поширеності, а також розробку і застосування ефективних антибактерійних та противірусних лікарських засобів, внаслідок цих хвороб щорічно помирають тисячі осіб (28-33 випадки на 100 тис. населення), хоча їх кількість і зменшується (з понад 17,2 тисяч у 2005 р. до 12,9 тисяч у 2013 р.). Провідною причиною смерті залишається туберкульоз (14-18 осіб на 100 тис. населення) та ВІЛ /СНІД (11-12 осіб на 100 тис. населення)

Сумарно, упродовж 1994-2013 рр. кількість захворювань, що входять до класу I «Деякі інорекційні та паразитарні хвороби», зменшилась на 23,3 \%, однак незважаючи на це, коефіцієнти достовірності апроксимації $\left(R^{2}=0,52\right.$ та $\left.R^{2}=0,35\right)$, які характеризують динаміку розвитку цієї групи хвороб, свідчать про нестійку тенденцію, що пов'язано з безперервною циркуляцією серед населення мікроорганізмів, що їх спричинюють. Зниження на 17,1 \% показника поширеності та на 18,1 \% інсрекційної та паразитарної захворюваності населення в 2014-2015 рр. могло бути обумовлено, серед іншого, й вилученням зі статистичного обліку даних з АР Крим, міста Севастополя та частини Луганської і Донецької областей.

На тлі загальної тенденції до зниження, серед осіб похилого віку спостерігається достовірне збільшення випадків вперше виявленої інфекційної та паразитарної патології $\left(R^{2}=0,9 ; p<0,01\right)$. Це впливає на фрормування загального показника інфекційної та паразитарної захворюваності, про що свідчить прямий кореляційний зв'язок ( $r=0,7 ; p<0,01)$.

Проведене ранжування регіонів країни за показниками інфекційної захворюваності виявило, що в 1994 р. найвищі показники захворюваності (1-5 ранг) спостерігались у Миколаївській області, м. Севастополь, АР Крим, Донецькій та Кіровоградській областях. 36 по 10 ранг мали Полтавська, Черкаська, Житомирська, Дніпропетровська області та м. Київ. 311 по 15 місця посідали Волинська, Одеська, Сумська, Закарпатська, Херсонська області. 16-20 ранг було присвоєно ІваноФранківській, Львівській, Луганській, Чернігівській, Запорізькій областям. Найнижчі ранги (21-27) за показниками захворюваності були у Хмельницькій, Чернівецькій, Рівненській, Київській, Вінницькій, Харківській та Тернопільській областях.

У 2013 р. 1-5 місця в рейтингу посідали Дніпропетровська, Донецька області, м. Севастополь, Одеська та Волинська області. 36 по 10 ранги мали АР Крим, 
Миколаївська, Запорізька, Кіровоградська, Харківська області. 311 по 15 місця посідали Івано-Франківська, Херсонська, Житомирська, Полтавська, Луганська області. 16-20 ранги були присвоєні Київській області, м. Києву, Львівській, Черкаській та Рівненській областям. 321 до 27 місця займали Чернігівська, Чернівецька, Хмельницька, Закарпатська, Вінницька, Сумська та Тернопільська області.

Упродовж 1994-2013 рр. Чернівецька, Тернопільська, Вінницька, Рівненська області не змінили свого розташування в шкалі рангів за показниками поширеності іноекційної патології і займали відповідно 20, 22, 23, 25, 27 місця. Значно покращилась ситуація 3 поширеністю хвороб (відбулось її зменшення) у м. Києві, Закарпатській, Миколаївській, Сумській, Житомирській, Полтавській та Черкаській областях (зайняли позиції на 5-13 пунктів нижче). Натомість, значно погіршилась епідемічна ситуація в Дніпропетровській, Одеській, Волинській, Харківській, Запорізькій та Київській областях (піднялись в рейтингу на 8-12 пунктів).

У 2015 р. (проти 2013 р.) ситуація практично у всіх областях погіршилась, вони піднялись в рейтингу, що свідчить про зростання рівня поширеності інфекційних хвороб. Винятком стали Луганська, Донецька області та м. Київ (зниження від 8 до 14 пунктів завдяки зменшенню в 2-3 рази показників захворюваності). У Дніпропетровській, Харківській і Запорізькій областях зниження в шкалі рейтингу складало від 1 до 4 пунктів. Однак, якщо різниця в бік росту чи зниження на декілька пунктів $€$ природною, тому що епідемічний процес $є$ динамічним, а крім того, на цій ситуації позначилось вилучення 3 обліку даних з АР Крим та м. Севастополя, які стабільно займали провідні позиції в рейтингу, то в Донецькій та Луганській областях показники зменшились, насамперед, через відторгнення частини території.

Для виявлення впливу різних фракторів, зокрема місця проживання населення, на ризик виникнення інфрекційної патології, було проведено ранжування регіонів за площею та щільністю населення. Встановлено, що найбільші території мають Одеська, Дніпропетровська та Чернігівська області. Однак, за щільністю проживання населення лідирували багато років поспіль мм. Київ, Севастополь та Донецька область. Найвищий показник щільності населення характерний для східного регіону та західних областей, а найменший - для полісся та півдня країни, особливо Херсонської та Миколаївської областей, хоча й у Чернігівській області він не досягає і половини від середнього показника по Україні. Припускаючи, що щільність проживання населення в регіонах країни може певним чином впливати на інфекційну та паразитарну захворюваність, сприяючи швидшому поширенню хвороботворних збудників, було досліджено ці показники для встановлення можливого зв'язку між ними за 1994 та 2013 рр. Кореляційний аналіз показав, що ці явища певним чином пов'язані, оскільки між ними існує прямий, хоча й достатньо слабкий зв'язок, коефіцієнт кореляції (r) становить 0,1. Розрахунки з використанням показників за 2015 р. виявили теж слабкий, однак зворотний зв'язок $(r=-0,25 ; p<0,05)$. Можливо, причина криється у посиленні міграційних процесів, і як наслідок виникнення, так званої, «прихованої» захворюваності, або ж через вилучення із статистичного обліку частини даних з тимчасово окупованих територій. Крім того, можна припустити, що на поширення інорекційних та паразитарних хвороб більший вплив має щільність проживання в конкретному населеному пункті чи помешканні, а також санітарно-гігієнічні умови його утримання. Для з'ясування впливу місця проживання (місто чи сільська місцевість) на рівень захворюваності, було досліджено існування зв'язку між часткою містян та захворюваністю і встановлено прямий, хоча й достатньо слабкий кореляційний зв'язок $(r=0,2)$. В 13 регіонах між рангами (за щільністю та інфекційною захворюваністю) різниця не перевищує 5 пунктів, а коефіцієнт кореляції $\left(r_{s}\right)$ становить 0,4 ( $\left.<<0,05\right)$, отже, значна кількість міських жителів може підвищувати ризик виникнення та поширення інфекційних хвороб.

Незадовільний стан природного навколишнього середовища та техногенної сфери призводить до негативних соціально-економічних наслідків, зокрема, через погіршення здоров'я населення, а відтак, збільшення видатків на медичну допомогу, а також витрат на соціальну допомогу внаслідок тимчасової непрацездатності. Крім того, це позначається на прямих збитках на виробництві внаслідок відсутності працівників, тощо. Сума збитків, завданих надзвичайними ситуаціями техногенного та природного характеру, щорічно сягає мільярдів гривень. Одним із найважливіших життєзабезпечуючих природних ресурсів $є$ атмосорерне повітря. У структурі фракторів, що фрормують ризик здоров'ю, перше місце займає повітряне середовище $(66,7 \%)$, друге харчові продукти (13,5 \%) і третє - шумове навантаження (12,6 \%). Надмірне аерозольне забруднення атмосорери негативно відображається на здоров'ї людей, провокуючи захворювання дихальної системи, загострення серцево-судинних захворювань. Крім того, забруднюючі речовини 3 атмосорерного повітря мають найширше розповсюдження та випадають у різні середовища. Приміром, атмоссрерні опади дають до 10 \% забруднення водних об єктів, значно забруднюють ґрунт тощо $[11,12,13]$

Для того, щоб оцінити вплив фракторів зовнішнього середовища, зокрема техногенного навантаження на здоров'я населення, було використано інтегральний 
показник - індекс людського розвитку регіонів (IЛP) [1, 14], який розраховується за методикою Інституту демограсрії та соціальних досліджень ім. М.В. Птухи НАН України. ІЛР нараховує 33 показники, що зводяться в 6 субіндексів за окремими аспектами людського розвитку: відтворення населення; соціальне становище; коморортне життя; добробут; гідна праця; освіта. Слід зазначити, що для України характерні певна диспропорція та протиріччя між розвитком окремих їі регіонів. Якщо до 2009 рр. за ІЛР провідне місце займала Закарпатська область, яка лідирувала за інтегральним індексом комфортного проживання, то в 2010-2013 рр. першість належала Харківській області завдяки найкращим показникам освіти та добробуту населення. Друге місце належало Чернівецькій області (перші позиції за розвитком соціального середовища та добробуту). На останніх місцях в ці роки були розташовані Житомирська (найгірші показники добробуту, освіти, ринку праці та відтворення населення), Кіровоградська (низькі показники відтворення населення та соціального середовища) та Херсонська області (низькі показники соціального середовища, добробуту та відтворення населення). Незважаючи на зростання ІЛР в цілому, відмінності між регіонами продовжують збільшуватись, відбувається поступове поглиблення розшарування регіонів. Більшість регіонів характеризуються значенням ІЛР меншим, ніж середній по Україні, і ця тенденція посилюється. Найменше регіони відрізняються за рівнем освіти та станом відтворення (коесріцієнт варіації показників за даними 2013 р. має значення нижче 5 \%), а от за станом соціального середовища вони значні (значення коефіцієнту - понад 20 \%). Спостерігається і посилення диореренціації регіонів за рівнем добробуту (коефріцієнт варіації збільшився на 4 пункти) [14].

Дослідниками вивчались зв'язки між різними соціально-економічними чинниками в розрізі регіонів країни, однак питанню кореляції рівня людського розвитку (як комплексного показника) та здоров'я населення уваги приділялось менше, ніж іншим проблемам. Разом з тим, умови середовища життєдіяльності впливають на здоров'я людини як прямо, так і опосередковано. Це особливо актуально для інфекційних та паразитарних хвороб, а тому було досліджено силу та характер зв'язків між захворюваністю та рівнем людського розвитку в регіонах України. У табл. 1 показано результати ранжування регіонів за поширеністю інфекційних хвороб (IX) та індексом людського розвитку (IЛP). Розрахунки показали, що коефіцієнт кореляції рангів (r) для оцінки динаміки IX та IЛP (окремо за кожним з показників в різні роки) становив 0,8-0,9, що вказує на наявність сильного прямого достовірного зв'язку $(p<0,01)$ та свідчить про те, що суттєвих змін у захворюваності насе- лення та розвитку регіонів упродовж цих років не відбувалось. При цьому, характер та напруженість зв'язку (r) між IX та IЛP були різними, коливаючись від -0,2 до 0,1 в різні роки, що, очевидно, обумовлено, зміною окремих показників, на яких базується розрахунок ІЛР, і які можуть по різному впливати на захворюваність, а тому, можливо, доцільно в подальшому детальніше вивчати роль окремих фракторів.

Найменший розрив у рангах за IX та IЛP (до 5 пунктів) у 2005 р. спостерігався в Івано-Франківській області (6/6), Черкаській (16/13), Рівненській (22/18), Сумській (23/19), Київській (14/10) та Запорізькій областях (20/17). У 2013 р. певна відповідність за рангами мала місце в Сумській (24/22), Полтавській (13/8), Рівненській (18/19), Луганській (14/16), Чернігівській (19/17), Запорізькій (7/6) областях та АР Крим (5/4). Дніпропетровська та Донецька області, приміром, мають низький рівень людського розвитку, разом з тим, за показниками поширеності інфекційних та паразитарних хвороб, ці області перебувають на перших місцях в рейтингу. Натомість Закарпатська та Чернівецька області, що вважаються депресивними регіонами, займають лідируючі позиції в рейтингу за ІЛР, є відносно благополучними щодо поширеності IX.

Незважаючи на те, що економічні показники враховуються і при розрахунку ІЛР, було проведено окремий кореляційний аналіз для пошуку зв'язків між рівнем доходів у регіонах (млн. грн.) та показниками інфекційної та паразитарної захворюваності. Виявлено, що між цими явищами існує достовірний сильний прямий зв'язок $(r=0,9, p<0,01)$. Разом з тим, кореляційний аналіз, проведений з урахуванням наявного доходу (у гривнях на одну особу), виявив хоча й прямий, однак значно меншої сили зв'язок ( $r=0,1 ; r=0,5)$. Можна припустити, що ця ситуація обумовлена не вищою захворюваністю в економічно стабільніших регіонах, а більшою кількістю звернень за медичною допомогою завдяки краще розвинутій та доступній медичній інфрраструктурі. Рівень економічного розвитку регіону, а не доходи конкретних громадян, визначають можливість системи охорони здоров'я виявляти та надавати медичну допомогу саме цій категорії хворих.

За умови, що здоров'я населення залежить від середовища життєдіяльності людини, було проведено кореляційний аналіз між можливістю населення регіонів споживати свіжу воду і ризиком виникнення хвороб органів травлення чи інфекційних хвороб, зокрема гастроентероколітів різної етіології. Встановлено, що між динамікою використання свіжої води (млн. м³) і показниками захворюваності на хвороби органів травлення (К00-К93) та інфекційні хвороби (А00-В99) існує достовірний прямий сильний зв'язок $(r=0,9 ; p<0,01)$. В роз- 
ОРИГІНАЛЬНІ ДОСЛІДЖЕННЯ

Таблиця 1

Ранжування регіонів за поширеністю інфекційних та паразитарних хвороб (IX)

та індексом людського розвитку (ІЛР)

\begin{tabular}{|c|c|c|c|c|c|c|c|c|c|c|}
\hline \multirow{2}{*}{ Область \Роки } & \multicolumn{2}{|c|}{2005} & \multicolumn{2}{|c|}{2010} & \multicolumn{2}{|c|}{2011} & \multicolumn{2}{|c|}{2012} & \multicolumn{2}{|c|}{2013} \\
\hline & $\mathrm{IX}$ & ІЛР & IX & ІЛР & IX & ІЛP & IX & ІЛР & IX & ІЛ $\mathrm{P}$ \\
\hline АР Крим & 9 & 4 & 6 & 5 & 6 & 9 & 6 & 6 & 5 & 4 \\
\hline Вінницька & 17 & 11 & 22 & 20 & 22 & 19 & 22 & 21 & 23 & 18 \\
\hline Волинська & 2 & 21 & 3 & 19 & 5 & 14 & 4 & 15 & 4 & 13 \\
\hline Дніпропетровська & 4 & 8 & 1 & 13 & 1 & 15 & 1 & 14 & 1 & 15 \\
\hline Донецька & 10 & 14 & 2 & 21 & 3 & 18 & 3 & 12 & 2 & 20 \\
\hline Житомирська & 1 & 23 & 8 & 25 & 11 & 25 & 10 & 25 & 12 & 25 \\
\hline Закарпатська & 24 & 7 & 23 & 3 & 25 & 3 & 12 & 2 & 22 & 5 \\
\hline Запорізька & 20 & 17 & 19 & 10 & 13 & 6 & 25 & 5 & 7 & 6 \\
\hline Івано-Франківська & 6 & 6 & 4 & 12 & 9 & 13 & 8 & 13 & 10 & 21 \\
\hline Київська & 14 & 10 & 12 & 4 & 12 & 7 & 14 & 7 & & 7 \\
\hline Кіровоградська & 12 & 25 & 11 & 24 & 10 & 24 & 11 & 24 & 8 & 23 \\
\hline Луганська & 13 & 22 & 17 & 18 & 16 & 20 & 15 & 11 & 14 & 16 \\
\hline Львівська & 18 & 3 & 20 & 7 & 18 & 4 & 16 & 4 & 16 & 3 \\
\hline Миколаївська & 5 & 15 & 9 & 15 & 4 & 11 & 5 & 8 & 6 & 12 \\
\hline Одеська & 3 & 12 & 7 & 8 & 8 & 10 & 2 & 10 & 3 & 9 \\
\hline Полтавська & 19 & 1 & 21 & 9 & 14 & 5 & 13 & 9 & 13 & 8 \\
\hline Рівненська & 22 & 18 & 16 & 14 & 20 & 16 & 18 & 19 & 18 & 19 \\
\hline Сумська & 23 & 19 & 24 & 16 & 23 & 21 & 23 & 23 & 24 & 22 \\
\hline Тернопільська & 25 & 9 & 25 & 11 & 24 & 12 & 24 & 17 & 25 & 10 \\
\hline Харківська & 7 & 2 & 5 & 1 & 7 & 1 & 9 & 1 & 9 & 1 \\
\hline Херсонська & 8 & 20 & 10 & 23 & 2 & 23 & 7 & 22 & 11 & 24 \\
\hline Хмельницька & 11 & 16 & 14 & 17 & 21 & 22 & 20 & 20 & 21 & 14 \\
\hline Черкаська & 16 & 13 & 15 & 6 & 15 & 8 & 21 & 16 & 17 & 11 \\
\hline Чернівецька & 21 & 5 & 13 & 2 & 19 & 2 & 17 & 3 & 20 & 2 \\
\hline Чернігівська & 15 & 24 & 18 & 22 & 17 & 17 & 19 & 8 & 19 & 17 \\
\hline
\end{tabular}

різі регіонів коефіцієнт кореляції (r ) між використанням свіжої води і інфекційними хворобами становив 0,5 $(p<0,05)$, і лише щодо гастоентероколітів невстановленої етіології зв'язок був зворотним $(r=-0,03)$. Парадоксальна, на перший погляд, ситуація, може бути обумовлена двома причинами. По-перше, кількість використаної свіжої води не гарантує її якість. Приміром, у 2013 р. в середньому по країні, 3,9 \% водогонів не відповідали санітарним нормам, зокрема 8,6 \% комунальних. У 63,2 \% випадків водогони не відповідали санітарним нормам через відсутність зон санітарної охорони, ще $24,1 \%$ не мали необхідного комплексу очисних споруд та 30,9 \% - знезаражуючих установок. Найбільша кількість водогонів, що не відповідали санітарним нормам, розташовані у Луганській (23,3\%), Донецькій (17\%), Херсонській (12,5 \%) областях. 3,8 \% проб води джерел централізованого водопостачання, досліджених за бактеріологічними показниками, не відповідали вимогам санітарного законодавства, зокрема 4,9 \% у Харківській області, 6,5 \% у Закарпатській, 6,9 \% у Миколаївській та 9,9 \% у Тернопільській областях. Якість питної води 3 джерел децентралізованого водопостачання ще гірша, 16,7 \% досліджених у 2013 р. проб не відповідали вимогам санітарного законодавства, зокрема, за бактеріологічними показниками. У 2014 р. було зареєстровано 2 та в 2015 р. - 3 спалахи вірусного гепатиту A, пов'язаних з водним фрактором передачі, зокрема, як припускали фрахівці, через вживання недоброякісної питної води 3 джерел централізованого водопостачання. Подруге, в 2013 р. у поверхневі водойми скидали стоки понад 1,7 тисяч об'єктів, у море - 66. Третина випусків у поверхневі водойми та більше 55 \% у море не відповідали за якістю очистки санітарним вимогам, що ставить під загрозу здоров'я населення через потрапляння збудників інфекційних хвороб та небезпечних хімічних сполук у джерела водопостачання.

ще одним з чинників, що може впливати на якість атмосфрерного повітря, води та ґрунту, є відходи життєдіяльності людини, як внаслідок промислового виробництва, сільського, лісового та рибного господарства, добувної промисловості і розроблення кар'єрів, переробної промисловості, постачання електроенергії та газу, 
будівництва, так і від домогосподарств. Всі відходи згруповано в 4 класи, зокрема до I класу небезпеки включено відпрацьовані люмінесцентні лампи; до II відпрацьовані чи пошкоджені акумуляторні свинцеві батареї, лужні акумулятори; до III - масла та моторні мастила, відходи піску, забрудненого настопродуктами, лакофрарбувальні відходи та інші речовини і матеріали; до IV - відпрацьовані шини, накладки гальмових колодок автомашин, брухт чорних та кольорових металів, макулатура, брухт абразивного інструменту, відходи зварювальних електродів, використаний спецодяг і взуття, матеріали і вироби з пластмаси, списане обладнання чи деталі, у т. ч. комп'ютерне обладнання, відходи деревини, будівельні тощо. У статистичних звітах за 1994 2009 рр. відображались дані по відходах I-ІІІ класів небезпеки; з 2010 р. - по відходах I-IV класів небезпеки. До 2009 р. відображались дані від економічної діяльності підприємств та організацій, з 2010 р. - з урахуванням відходів, утворених у домогосподарствах. Після 2013 р. державні звіти укладались без даних з тимчасово окупованої території Автономної Республіки Крим, м. Севастополя та території зони проведення антитерористичної операції.

Кореляційний аналіз виявив середньої сили прямий зв'язок $(r=0,4 ; p<0,05)$ між показниками всіх вироблених та утилізованих відходів (тис. тон на рік) та інфрекційною захворюваністю в динаміці за 1994-2015 рр. Між кількістю відходів від домогосподарств та інфекційною захворюваністю виявлено слабкий кореляційний зв'язок, однак через незначний проміжок часу, протягом якого

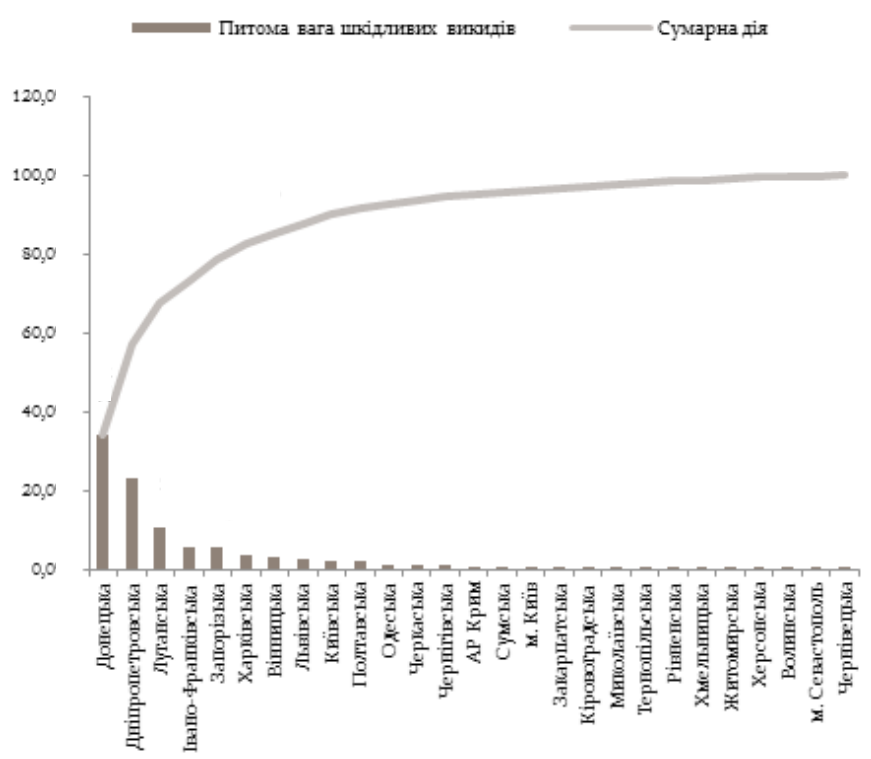

Мал. 1. Обсяги шкідливих викидів в атмосфрерне повітря в Україні за 2005 р. здійснюється облік цих відходів, статистична достовірність отриманих результатів низька. Між кількістю відходів, які належать до I-III класів небезпеки, та поширенням інфекційних та паразитарних хвороб завдяки кореляційному аналізу виявлено середній за силою прямий зв'язок у 2010 р.(r=0,3,), а от щодо відходів IV класу небезпеки кореляційний зв'язок дещо сильніший $(r=0,4 ; p<0,05)$. У 2012 p. ситуація не змінилась, а в 2013 р. посилилась $(r=0,5)$. При цьому в динаміці кількість відходів корелювала з регіональним розподілом $(r=0,9 ; p<0,01)$, що може бути обумовлене різною кількістю підприємств та організацій, що генерують відходи, а також системою їх утилізації.

Між динамікою усіх викидів забруднюючих речовин в атмосфрерне повітря та від стаціонарних джерел забруднення і ризиком виникнення інфекційних та паразитарних хвороб існує прямий зв'язок, про що свідчать коефріцієнти кореляції, які складають 0,3 та 0,5, відповідно $(p<0,05)$. Натомість, між пересувними джерелами забруднення та захворюваністю виявлено зворотний зв'язок ( $r=-0,3 ; p<0,05)$. Слід зазначити, що між інфрекційною захворюваністю та обсягами шкідливих викидів в регіонах країни встановлено існування сильного прямого зв'язку. Коефіцієнт кореляції в різні роки спостереження (1995, 2005, 2013 рр.) становив 0,9 ( $<<0,01)$. Як свідчать дані діаграми Парето, 6 областей (Донецька, Дніпропетровська, Луганська, Запорізька, Івано-Франківська та Харківська) обумовлюють 80,0 \% всіх шкідливих викидів в атмосферне повітря (мал. 1, мал. 2).

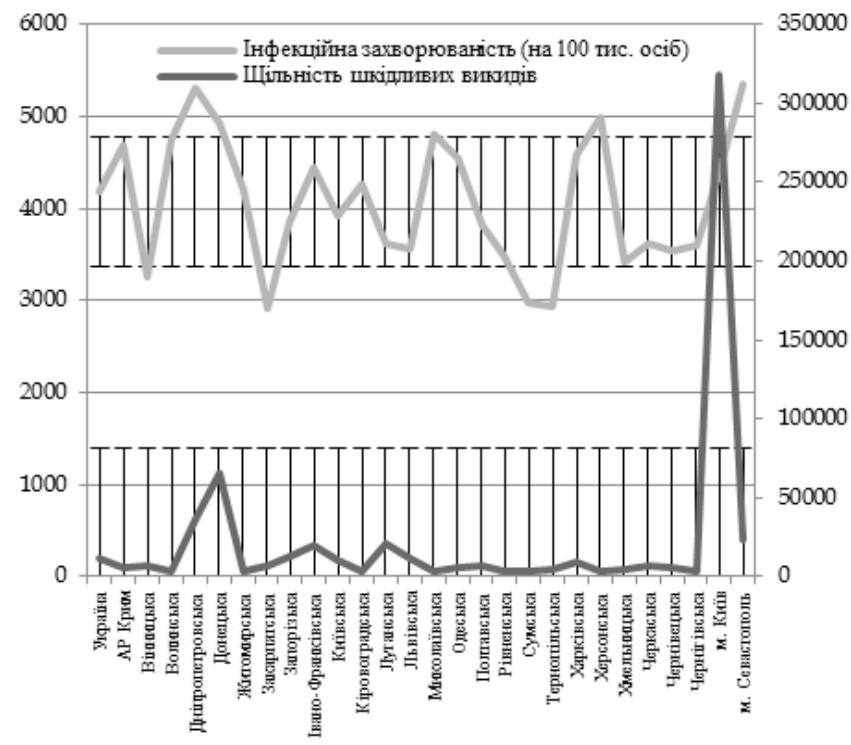

Мал. 2. Щільність шкідливих викидів в атмосорерне повітря та інтенсивність інфекційних хвороб в України за 2011 р. 
Виявлено існування достовірного сильного прямого зв'язку між обсягами шкідливих викидів та захворюваннями органів дихання в розрізі регіонів країни $(r=$ $0,9 ; p<0,01)$. Можна припустити, що значне поширення хвороб органів дихання може підвищувати ризик виникнення інорекційної патології з аналогічною локалізацією.

Аналіз ризиків для здоров'я населення в регіональному аспекті $€$ надзвичайно актуальним зважаючи на те, що на території областей з великою кількістю промислових об'єктів відбуваються бойові дії, що окрім прямої небезпеки для життя людей, загрожує й виникненням природно-техногенної катастрофри, наслідки якої можуть бути непередбачуваними. Фахівці різних галузей, насамперед медичної, повинні бути готові до ліквідації негативного впливу на здоров'я небезпечних фракторів, мати напоготові запас відповідних медичних препаратів, антидотів тощо.

I насамкінець, крім всіх вищезазначених фракторів оточуючого середовища, які можуть зумовлювати чи сприяти виникненню інфрекційних та паразитарних хвороб, проаналізовано кореляційний зв'язок між захворюваністю та обсягом пасажирообігу в динаміці за 19942015 рр. Це питання вимагає особливої уваги зважаючи на те, що останніми десятиріччями значно зросла туристична активність населення та трудова міграція. Розширення туристичних маршрутів може загрожувати завезенням у країну збудників інфекційних хвороб, що раніше не зустрічались на цій території. Кореляційний аналіз виявив між обсягами пасажирообігу та інфекційними і паразитарними хворобами прямий середньої сили зв'язок ( $r=0,4, p<0,05)$. Крім того, не слід забувати й про міграційні процеси в межах країни, оскільки чисельні та регулярні переміщення як цивільного населення, так і військовослужбовців з різних природно-кліматичних зон та територій, що межують з осередками природно-вогнищевих хвороб на території сусідніх держав, теж повинно стати предметом поглибленого вивчення з наступним впровадженням адекватних профрілактичних та протиепідемічних заходів.

Отже, від соціально-економічного та екологічного становища в регіонах залежить стан здоров'я населення, яке проживає на цій території, а тому підвищення соціальних стандартів життя сприятиме покращенню здоров'я спільноти й зменшенню тягаря соціальних хвороб, до яких насамперед належать іноекційні захворювання.

\section{Висновки}

1. В Україні погіршується стан здоров'я населення, про що свідчить збільшення на 55 \% показника поширеності хвороб за всіма класами та Індекс накопичення хвороб $(1,4)$.
2. Інфекційна та паразитарна захворюваності набули тенденції до зниження, їх частка в загальній структурі хвороб не перевищує 4 \%, однак зростає кількість залучених в епідемічний процес осіб похилого віку.

3. Інфекційна та паразитарна захворюваність має регіональні відмінності, зокрема висока поширеність цієї патології притаманна для АР Крим, Волинської, Дніпропетровської, Донецької, Житомирської, Миколаївської, Одеської, Івано-Франківської областей та м. Севастополь, а найнижча - для Закарпатської та Тернопільської областей.

4. На іноекційну захворюваність, з поміж іншого, впливають щільність проживання населення ( $r \mathrm{~s}=0,4$; $\mathrm{p}<0,05)$, а також рівень людського розвитку регіонів, економічні показники ( $r=0,9 ; p<0,01)$, від яких залежить доступність медичної допомоги.

5. Ризик виникнення інфекційних хвороб зростає внаслідок погіршення умов середовища життєдіяльності людини, зокрема через відсутність у населення регіонів можливості використовувати не лише свіжу $(r=0,9$, p<0,01), а насамперед безпечну воду; високий рівень вироблених відходів ( $r=0,4 ; p<0,05)$, насамперед тих, що належать до I-III класів небезпеки $(r=0,3 ; p<0,05)$; збільшення обсягів викидів забруднюючих речовин в атмоссрерне повітря від різних джерел забруднення $(r=0,9 ; p<0,01)$ та через інші фрактори, які прямо чи опосередковано можуть впливати на здоров'я населення.

\section{Література}

1. Галузева звітність МОз України, Державної санітарно-епідеміологічної служби та Державної ветеринарної та фрітосанітарної служби України.

2. Мировая статистика здравоохранения 2014 г.: значительный рост продолжительности жизни [Електронний ресурс]. Режим доступу: http://www.who.int/mediacentre/news/releases/2014/ world-health-statistics-2014/ru/

3. World Health Statistics 2013 [Електронний ресурс]. Режим доступу: www.who.int/gho/.../world_health_statistics/EN_WHS2013_ Full.pdf

4. Bulletin of the World Health Organization: special collection [Russian], volume 92, issues 7-12, 2014. [Електронний ресурс]. Режим доступу: http://apps.who.int/

5. Petersdorf, R. G.; Root, R. (1992). Справочник, 1 т. Болезни, вызванные биологическими агентами и фракторами окружающей среды. Основные аспекты проблемы инсекционных болезней. Внутрішні хвороби, під редакцією Т. Р. Харрісона. Переклад з англ. М. : Медицина. 3430 с.

6. Улучшение состояния окружающей среды и здоровья в Европе: насколько мы продвинулись в достижении этой цели? (2015). Копенгаген; Европейское региональное бюро ВОЗ; С. 143. [Електронний ресурс]. Режим доступу: http://www.euro.who. int/ru. - Назва з екрану.

7. Андрейчин М. А. (2015). Військова епідеміологія з епідеміологією надзвичайних ситуацій. Тернопіль: ТДМУ. 320 с.

8. Improvingen vironment and health in Europe: howfarhavewegotten? /WHO Regional Office for Europe. Copenhagen 
[Електронний ресурс]. Режим доступу: www.euro.who.int/_data/ assets/pdf file/0019/276103/Improvin...

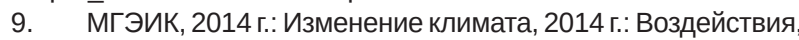
адаптация и уязвимость - Резюме для политиков / [Електронний ресурс]. Режим доступу: https://www.ipcc.ch/pdf/assessment-report/ ar5/wg2/ar5_wgll_spm_ru.pdf

10. World health statistics 2010 / [Електронний ресурс]. Peжим доступу: http://www.who.int/whosis/whostat/RU_WHS10_Full. pdf?ua=1

11. Войтенко, В. П., Писарук, А. В., Кошель, Н. М., Ахаладзе, М. Г., Мєхова, Л. В. (2013). Смертність внаслідок інсекційних та паразитарних хвороб населення в містах та сільській місцевості країни: медико-демографічні та соціальні аспекти - (2011) - Социальная геронтология и герогигиена «Пробл. старения и долголетия», 22, 2, 185-201.

12. Подаваленко, А. П. Наукове обґрунтування епідеміологічного нагляду за контрольованими крапельними інфекціями у регіонах України з різною екологічною ситуацією: дис. ... д-ра мед. наук [Електронний ресурс]. Режим доступу: http://duieih.kiev. ua/diser_Podavalenko.pdf

13. Боев, В. М., Дунаев, В. И., Шагеев, Р. М., Фролова, Е. Г. (2007). Гигиеническая оценка формирования суммарного риска популяционному здоровью на урбанизованных территориях. Гиг. и сан., 5, 12-14.

14. Динаміка Індексу регіонального людського розвитку, 2004-2014 рр. [Електронний ресурс]. Режим доступу: http://www. idss.org.ua/ukr index/Dynamic ua.pdf

15. Статистична інформація [Електронний ресурс]. Режим доступу: http//www.ukrstat.gov.ua/

\section{THE IMPACT OF ENVIRONMENTAL FACTORS OF HUMAN ACTIVITY ON THE RISK OF INFECTIOUS DISEASES}

\section{I.H. Markovych, I.F. Markovych}

National Academy of Medical Sciences of Ukraine, Ukrainian Military Medical Academy (Kyiv)

SUMMARY. This article defines the issue of infectious diseases and outlines their general trends and regional variations since the population of Ukraine is being involved in the epidemic process annually and only 8-9 million people appeal for the medical help. In order to establish the dynamics of the infection process, the retrospective epidemiological analysis was conducted. It is based on the study of long-term morbidity of the ukrainian population according to the reports of the Ministry of Health of Ukraine and the State Sanitary and
Epidemiological Supervision. The calculation of the correlation coefficient revealed the high connection density between the human environmental factors and the risk of infectious diseases. Also, the simple ranking method availed to order the regions by their importance according to the different criteria: amount of the population, human development level, the indices of infectious diseases etc.

The epidemiological analysis with the constructed trend model determined that the deterioration of health is being observed in Ukraine. It can be evidenced by an increase of the disease prevalence of all classes (in $55 \%$ ) and by the Disease Accumulation Index $(1,4)$. Infectious and parasitic diseases tend to decrease, their percentage (the unit weight) in the total disease structure does not exceed $4 \%$. However, the number of the older adults, involved in the epidemic process, increased. The morbidity has also the regional differences, in particular, the highest disease prevalence is inherent in Crimea, Volyn, Dnipropetrovsk, Donetsk, and the lowest - in Transcarpathian and Ternopil regions.

Furthermore, the infectious diseases are affected by the population density $(r s=0,4 ; p<0,05)$ and human development level in the regions, also by economic indicators $(r=0,9 ; p<0,01)$, which are crucial for the availability of medical care. The risk of infectious diseases increases due to: deterioration of the environmental conditions of human life, especially because of the inability to use not only fresh ( $r=0,9$; $p<0,01)$ but foremost the safe water; high level of waste $(r=0,4 ; p<0,05)$; increased level of the pollutants in the air $(r=0,9 ; p<0,01)$ and other factors that (in-)directly affect health of the population.

Hence, the socio-economic and ecological situation in the regions influences the health of people who live in these areas. Therefore, the ammended social standards will improve the health level and reduce the burden of the social disorders, which primarily include the infectious diseases.

Key words: morbidity, prevalence, retrospective epidemiological analysis, correlation analysis.

Отримано 11.09.2016 р. 